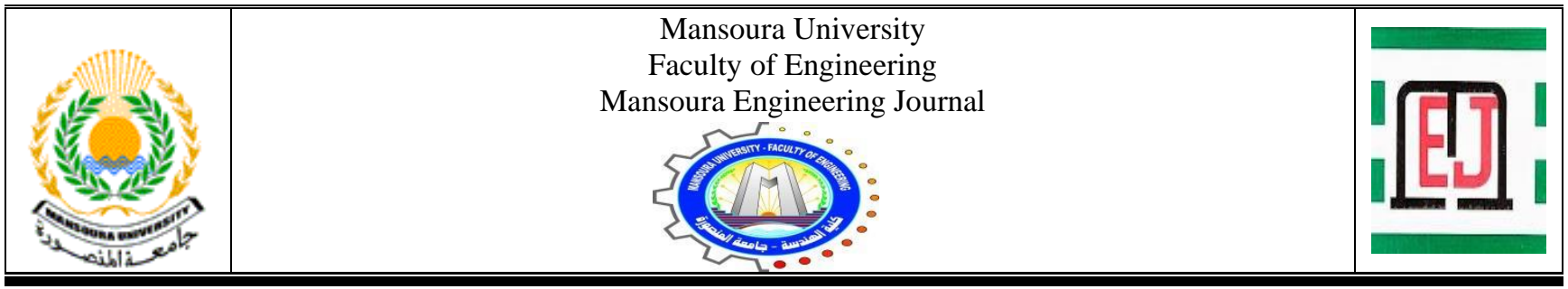

\title{
A Strategy for Achieving Sustainable Urban Development in Coastal Informal Areas Through A Participatory Approach
}

\author{
Reem Kamel Elnady*, Asmaa Nasr El-din Elbadrawey and Alaa El-Eashy
}

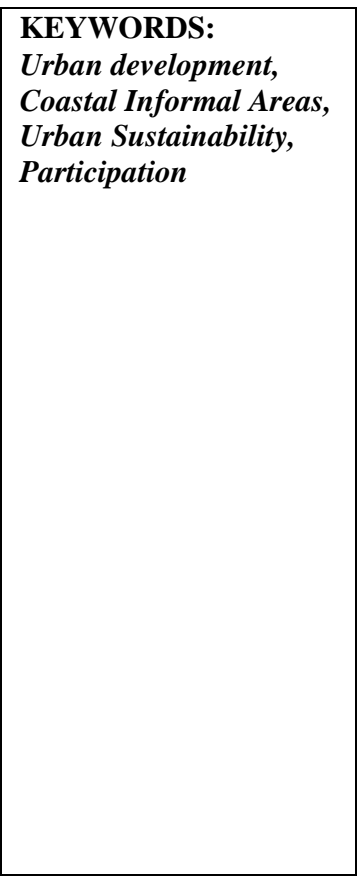

Abstract - Coastal areas have highly productive economic values for its residents, with huge potentials in fisheries and marine resources. The human factor with social capitals is vital potential in these coastal areas. The inhabitants work on fishing activities, intermediary traders, and other coastal related businesses. However, some of these areas are characterized with unplanned areas, poor livelihood, deteriorated buildings, with no green or public spaces. Moreover, these areas also suffer due to its far locations from cities' centers and their eliminating from the urban development plans. In general, these problems have transformed them into coastal informal areas.

Previous studies proved that there is no common methodology for dealing with coastal informal areas in Egypt. Furthermore, there is a gap between development plans and realities as they only focus on urban upgrading without considering participatory approaches, human factor, or spatial characteristics. Hence, this paper aims to formulate a strategy for achieving urban sustainability in the upgrading of coastal informal areas using a participatory approach. A comparative analysis is carried out for three coastal case studies in Indonesia, Nigeria, and Egypt to evaluate the impacts of urban upgrading using a participatory approach according to the dimensions of sustainability: social, economic, and environmental. Finally, the evaluation ends with recommendations for a participatory framework to attain sustainable upgraded coastal informal areas in Egypt. The proposed framework forms of eight drivers for attaining sustainability; economic inclusion, financial sustainability, cultural preservation, spatial inclusion, social and human capital, quality of life, environmental quality, and urban management.

Received: (02 October, 2021) - Revised: (13 December, 2021) Accepted: (15 December, 2021)

*Corresponding Author: Reem Kamel Elnady, Teaching assistant at Horus University \& MSc. Student at the Architectural Engineering Dept. Faculty of Engineering, Mansoura University (e-mail: relnady@horus.edu.eg) Alaa EL-Eashy, Professor at the Architectural Engineering Dept. Faculty of Engineering, Mansoura University (e-mail: arabeskal_arch@yahoo.com)

Asmaa Nasr El-din Elbadrawey, Lecturer at the Architectural Engineering Dept. Faculty of Engineering, Mansoura University (e-mail: asmaaelbadrawy@gmail.com)

\section{INTRODUCTION}

7 HE challenge of informal areas is the most serious urban concern facing the world nowadays. According to UN-HABITAT, the number of informal areas dwellers has increased to one billion people and if the situation continues, the number is expected to be 2 billion people in 2030 (A. Ghoneim, B. Salem, \& Hassan, 2014). These areas are chaotic, unsafe, and consume many resources while suffering from bad living conditions. This low-quality environment is caused because of lack of comprehensive planning, negligence of government 
authorities, insufficient infrastructure, poor housing quality, and the land tenure problems.

This research mainly discusses the problem of informal coastal settlements, located on water bodies as, the riverside, the shoreline or lakes, where the bulk of the population work as fishermen. However, these coastal areas have major contributions to the formal fishing economy and the informal one as well, but most of fishermen still live in negligible economic and environmental conditions ( Fajrin, Faqih, \& Septanti, 2018). Thus, there is an essential need for upgrading and managing these coastal informal areas to get the most out of its spatial and economic values.

Despite the initiatives and goals that have been launched over the years within national and global level to eradicate this pandemic, but many of them were criticized for being topdown process in which marginalized people were not being reached or involved (Vaidya \& Mayer, 2016). Moreover, the methods used are conducted to improve physical urban aspects only, neglecting other aspects that also affect the urban context as social, environmental and economic aspects. For these reasons, there is a need to find a sustainable way to transform these coastal informal areas into an effective, sustainable, productive, environmentally, economically and socially improved settlements.

Slum upgrading projects with the core of participatory approaches for improving and enhancing the quality of life have been used and developed in many countries over the world. Previous studies have showed that including communities in the decision-making process, is the first step for achieving urban sustainability. The engagement of various communities and stakeholders ensures that the upgrading activities are put forward to address community's specific needs and no one is Left behind. Therefore, in this research participation is used as the appropriate approach to handle the coastal urban characteristics, improve the coastal urban quality and achieve sustainable urban development in coastal informal settlements.

\section{A. The Problem}

There is a global interest on promoting strategies aiming towards achieving sustainable urban development in informal areas. Also, the UN and its partners in Egypt are working towards achieving the Sustainable Development Goals, but there is still a gap between development agenda and development realities in Egypt. Furthermore, there is not a common methodology that considers dwellers' needs in coastal informal settlements and upgrade through participatory approach. In other words, it can be said that dealing with informal areas in Egypt is done through solo case by case and there is no obvious framework to follow.

\section{B. Aim of Research}

The research' main aim is to formulate a framework for sustainable coastal slum upgrading in Egypt using a participatory approach to enhance the quality of life for its dwellers. To attain this aim, a comparative analysis of three coastal informal case studies for sustainable urban upgrading in Indonesia, Nigerian and Egypt to evaluate its principles, strategies and sustainable outcomes to reach a more structured methodologies that fit with the Egyptian coastal context. This is concluded by recommendations to help the researcher design the framework applied in Egypt.

\section{METHODOLOGY}

The research methodology is based on theoretical research and comparative analysis:

- Theoretical research is for studying the concept of coastal informal areas, analysing their potentials and problems. The research also focused on urban interventions in urban upgrading projects, highlighting the participatory urban upgrading approach as the best practice leading to sustainable outcomes.

- Analytical research has been used for studying sustainable urban interventions in three case studies from various coastal areas to get recommendations and formulate the appropriate framework that could be applied in Egypt.

\section{UNDERSTANDING THE MEANING OF COASTAL INFORMAL AREAS}

\section{A. Definition of Coastal Informal Settlements}

The coastal zone is the meeting area between the water bodies and the land. The different natural resources available in such zones provide various opportunities to the inhabitants. Inhabitants of coastal areas are not fully dependent on fishing activities for livelihood, but they also work on other sectors as marine tourism, shipping, small-scale traders, and other coastal related industries ( Fajrin, Faqih, \& Septanti, 2018). Regardless of the economic potentials in commercial fishing and marine resources, many of the dwellers especially fishermen still suffer from poverty, indigence and inequality, and live in a low environmental and economic conditions (Wardhani D. , 2017).

Although its strategic site and its nearest to the livelihood as fishermen, many coastal settlements are growing into slums due to the emergence of the population, illegal settlements (squatters) and the absence of building regulations (Sunarti, 2009). The urban fabric of coastal settlements is mainly described by a mixture of informality and complexity. In underdeveloped countries, many coastal settlements have characteristics of slum environment with problems in physical aspects such as: difficult in accessibility, interruption of roads, poor connectivity with nearby neighborhoods, as well as issues related to unemployment and low income that inhabitants confront. Hence, this low income is vastly affecting their capability to maintain their living environment (Sulistyo \& Widjajanti, 2018). Furthermore, the poor 
educational background of fishermen drives them to be uncaring to improve the quality of their living conditions.

To conclude, the researchers used this terminology to describe coastal regions with informal urban mixture, severe living conditions and characteristics of informal areas. Such conditions also exit in many informal coastal communities all over Egypt on the Red Sea coasts, Mediterranean Sea coasts or the River Nile coasts. Figure. 1

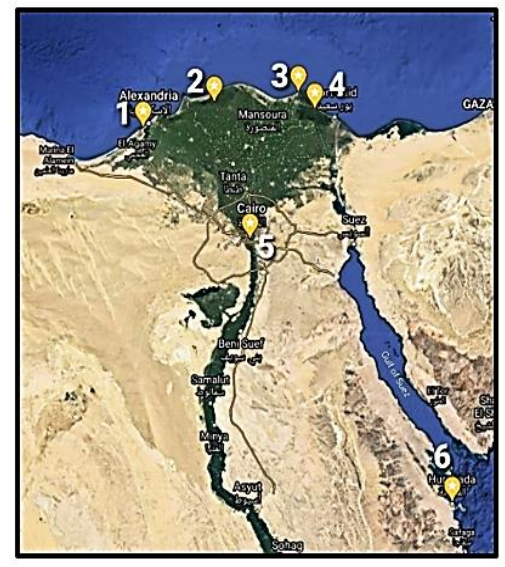

\begin{tabular}{c|c}
\multicolumn{2}{c}{$\begin{array}{c}\text { Coastal Informal Areas } \\
\text { in Egypt }\end{array}$} \\
\hline 1 & Al Max, \\
& Alexandria \\
2 & Al Shakhlubah, \\
& Kafr El Sheikh \\
3 & Ezbet Al Burj, \\
& Damietta \\
4 & Al Manzalah, \\
& Dakahlia \\
5 & Jazirat Al \\
& Qursayah, Giza \\
6 & Fishermen's \\
& Area, Hurghada
\end{tabular}

Figure.1: Example of Location of Coastal Informal Settlements in Egypt, Source: Google maps, edited by the researchers.

\section{B. Characteristics of Coastal Informal Settlements (Social- Physical-Economic) Dimensions}

The following specifies the characteristics of coastal slums that can be seen from the economic, physical and social aspects of the city, Source: ( Fajrin , Faqih, \& Septanti, 2018), Figure.2

\section{Coastal Informal Areas: Things are not always What They Seem}

From the researchers' observation, coastal informal areas in Egypt are different from one another in physical characteristics. One main type consists of buildings with medium height up to six floors, high density, with brick and reinforced concrete buildings such as Ezbet Elborj, Damietta. Another type of coastal informal areas consists of low building height up to three floors as a maximum, made by contemporary building materials as wood and straw. These coastal informal communities are to some extent self-financed and self-help communities in terms of the daily needs of the residents. These are merits which many urban planners and sustainability policies are admiring for.

\section{Advantages of Living in Coastal Informal Areas}

The researchers have tried to focus on a few advantages of coastal informal areas that support positive aspects of the residential environment, they are the following ${ }^{1}$ :

\footnotetext{
${ }^{1}$ The researchers also relied on the literature work by Shehayeb (2009) on her article "Advantages of living in informal areas" as a guide during the
}

- Self-Sufficiency: All the residents needs could be satisfied in the area

Coastal communities are self-sufficient communities for being full of natural resources and other related small enterprises that meet the needs of the residents especially fishermen. Moreover, they also encourage women work in small and home-based fisheries industries as fish processed products for income improvement. This helps to attain a sustainable economy.

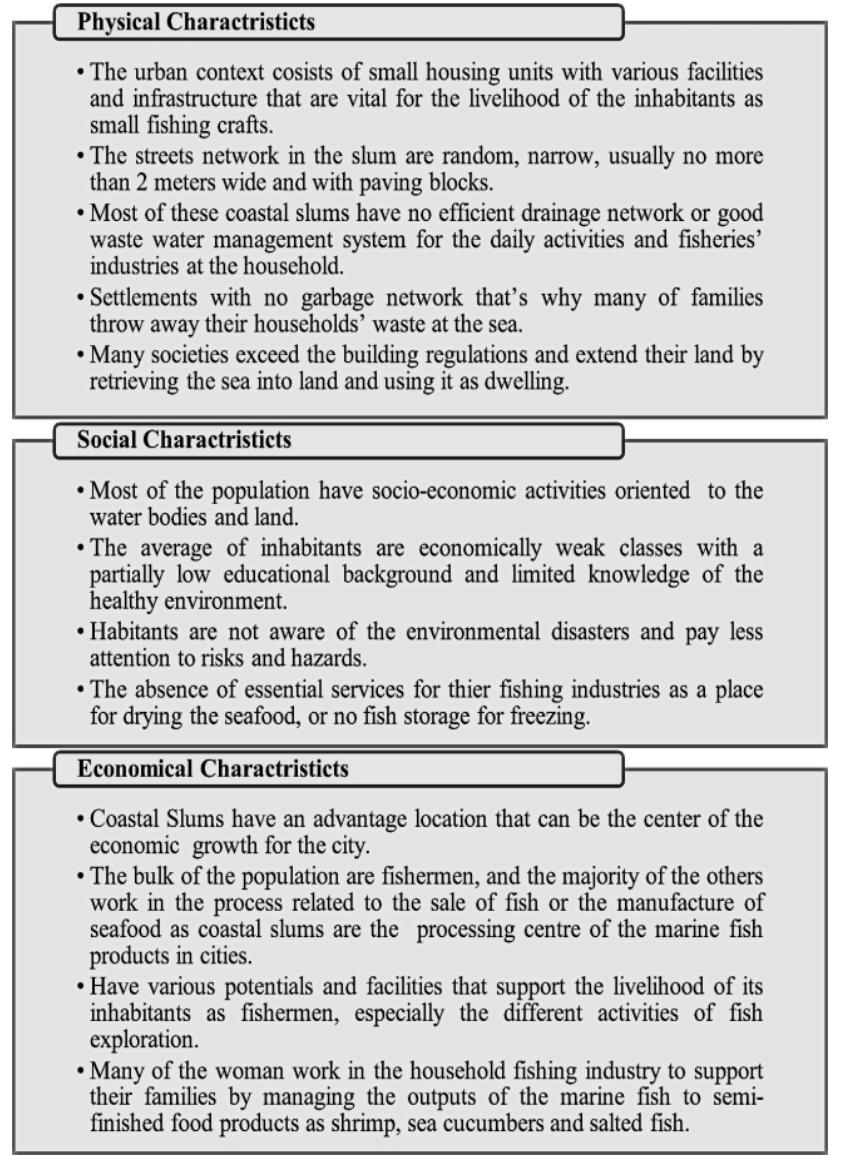

Figure.2: Characteristics of Coastal Informal Settlements, by the researchers basded on observations from filed visits, ( Fajrin , Faqih, \& Septanti, 2018), Invalid source specified. \& Invalid source specified..

\section{- No Travel to Work Distance - Walkability}

Another advantage is the proximity to work from home locations. This benefit is evident in many coastal areas, such as Ezbet Elborj, Damietta, where the bulk of dwellers works as fishermen at the shorelines and certainly, they go to work on foot. Others work in fish related industries in/around the same zone.

\section{- Participation}

The most noticed during sites observations and interviews that people are ready to participate in maintaining their own places. They do efforts quite successfully in public gardening,

research and interviews with residents of Ezbet Al Burj city in Damietta to explore the hidden attractions of coastal informal areas (Shehayeb, 2009). 
street lighting and street cleaning in their residential narrowwidth streets. People manage the cleanliness of what they feel is theirs. Their participation is limited when it's related to main streets that should be the governmental organizations' responsibilities.

\section{- Sense of Ownership: My street - my home}

The residents of coastal informal areas feel that their streets are the extension of their homes. Their street act as 'near home environment' that is private and protected where children can play. Many women in coastal areas consider their homes as a production unit and do work in front of their homes as peeling shrimps or selling vegetables. All these activities help build community ties, social basis and sense of responsibility towards the community.

\section{- Sense of Safety}

People are out on the streets, and they know each other through strong community ties, as a result there are few opportunities for ringleaders to harass the neighborhood. Therefore, it is fortunate that most residents describe their coastal informal areas as moderately safe environments for their families.

\section{- Building Community Social Solidarity}

The residents in coastal informal areas depict the sense of responsibility, collaboration, the presence of family connections, social activity and companionship as the advantages of living there. Inhabitants confirm the values of the community, the good neighbor relations, and social solidarity pleased within the neighborhood. These advantages are the main components of community building.

\section{D.The Challenges \& Potentials of Coastal Informal Areas in Egypt (SWOT Analysis)}

Figure.3 shows a SWOT analysis for coastal informal settlements.

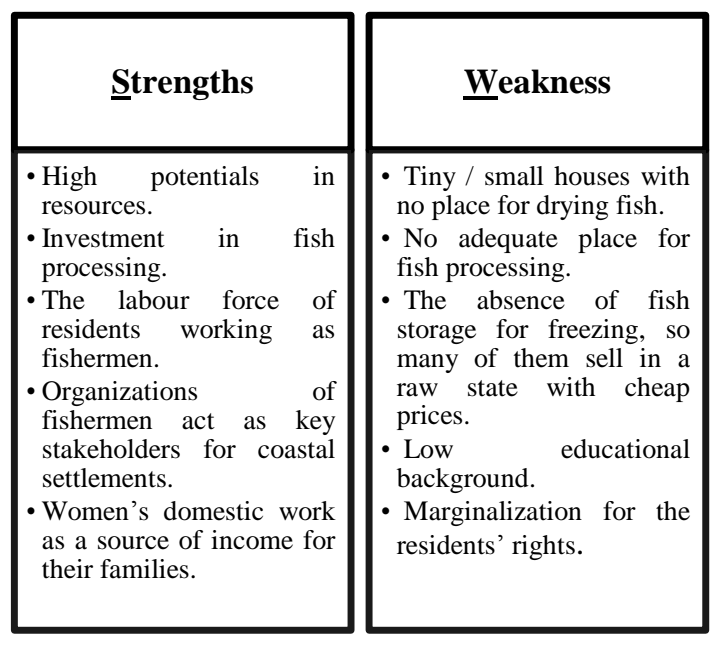

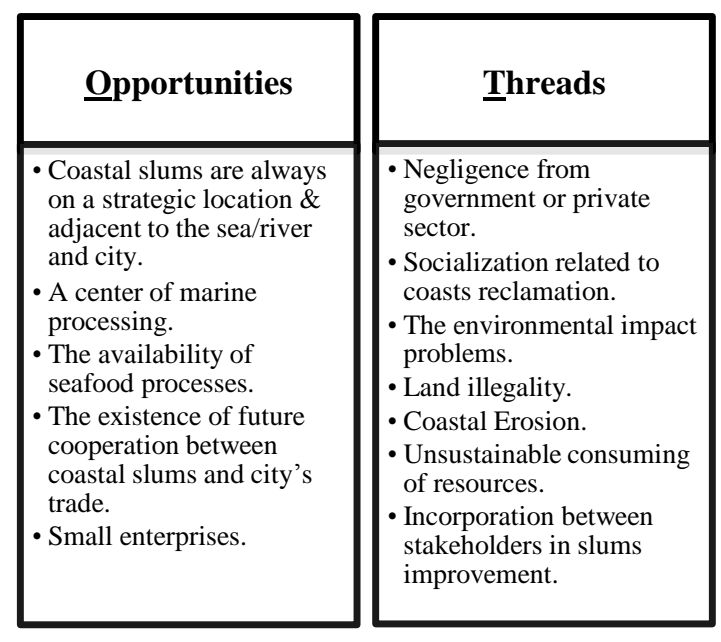

Figure.3: SWOT Analysis for Coastal Informal Settlements, by the researchers, based on observations from site visits.

\section{DEALING WITH COASTAL INFORMAL AREAS}

\section{A. Different Interventions Through Actions}

The governments' approaches towards informal settlements vary in practices and policies, so the following section elaborates more about the different possible approaches to deal with the informal through the different literature and practices. Table 1

\section{TABLE 1}

CONCLUSION OF URBAN DEVELOPMENT APPROACHES IN INFORMAL AREAS BY THE RESEARCHERS

\begin{tabular}{|c|c|c|}
\hline & Advantages & Disadvantages \\
\hline Negligence & $\begin{array}{l}\text { Considered as a relief } \\
\text { for the government and } \\
\text { the stakeholders as they } \\
\text { do not need to invest } \\
\text { money in developing } \\
\text { these areas. }\end{array}$ & $\begin{array}{l}\text { - Marginalize inhabitants } \\
\text { of the informal areas, and } \\
\text { not even include them on } \\
\text { city maps or documents. }\end{array}$ \\
\hline $\begin{array}{l}\text { Eviction } \\
\text { (Evacuating by } \\
\text { force) }\end{array}$ & $\begin{array}{l}\text { Common approach } \\
\text { used by decisions- } \\
\text { makers to use the empty } \\
\text { land after the eviction as } \\
\text { an opportunity for } \\
\text { investment by the } \\
\text { private market. }\end{array}$ & $\begin{array}{l}\text { - Deportation of families } \\
\text { without any negotiations, } \\
\text { alternative housing, or } \\
\text { compensation ( Saad, } \\
\text { Fikry, \& Hasan, 2019). } \\
\text { - Increasing poverty due } \\
\text { to tearing down vital } \\
\text { sources of income and } \\
\text { social bonds between } \\
\text { inhabitants. }\end{array}$ \\
\hline $\begin{array}{l}\text { Resettlement } \\
\text { (Clearance \& } \\
\text { Relocation) }\end{array}$ & $\begin{array}{l}\text { Enhance the use of } \\
\text { land and property that } \\
\text { slum dwellers inhabit } \\
\text { (Flinck, 2017). } \\
\text { - Reusing the land of } \\
\text { the previous slums by } \\
\text { the private market. }\end{array}$ & $\begin{array}{l}\text { - People have no access } \\
\text { to their livelihood or their } \\
\text { jobs ( Saad, Fikry, \& } \\
\text { Hasan, 2019). } \\
\text { - The high costs of } \\
\text { resettlements including the } \\
\text { clearance costs and the } \\
\text { costs of new housing and } \\
\text { services. } \\
\text { - Resettling in high rise } \\
\text { building with no space for } \\
\text { home-based businesses } \\
\text { which is common among } \\
\text { slum dwellers. }\end{array}$ \\
\hline
\end{tabular}




\begin{tabular}{|c|c|c|}
\hline $\begin{array}{l}\text { Redevelopment } \\
\text { (Clearance \& } \\
\text { Site } \\
\text { Development) }\end{array}$ & $\begin{array}{l}\text { Enhance the quality } \\
\text { of life for the slum's } \\
\text { residents. } \\
\text { The new built } \\
\text { environment becomes } \\
\text { suitable for the } \\
\text { inhabitants ( Saad, } \\
\text { Fikry, \& Hasan, 2019). }\end{array}$ & $\begin{array}{l}\text { - Long process. } \\
\text { - High Costs for } \\
\text { providing temporary } \\
\text { housing and other costs for } \\
\text { reconstructing the area ( } \\
\text { Saad, Fikry, \& Hasan, } \\
\text { 2019). }\end{array}$ \\
\hline $\begin{array}{l}\text { Upgrading in } \\
\text { Place (Self- } \\
\text { help \& In-site } \\
\text { Upgrading) }\end{array}$ & $\begin{array}{l}\text { Maintain social ties ( } \\
\text { Saad, Fikry, \& Hasan, } \\
2019 \text { ). } \\
\text { - Increase the quality } \\
\text { of life through } \\
\text { upgrading. } \\
\text { neonsidering the } \\
\text { needs of slum } \\
\text { inhabitants (Flinck, } \\
\text { 2017). } \\
\text { idreserve the local } \\
\text { identity and the existing } \\
\text { urban fabric. It poses a } \\
\text { chance for a more socio- } \\
\text { cultural development } \\
\text { (Abdelhalim, 2010). }\end{array}$ & $\begin{array}{l}\text { - It mainly depends on } \\
\text { international aid projects } \\
\text { without the involvement of } \\
\text { the local government. } \\
\text { - After the upgrading the } \\
\text { communities fail to } \\
\text { maintain the facilities or } \\
\text { follow the steps and the } \\
\text { government may not } \\
\text { complete providing } \\
\text { services (UN-Habitat, } \\
\text { 2003). } \\
\text { - A long-term process and } \\
\text { sometimes it could be } \\
\text { frustrating. }\end{array}$ \\
\hline
\end{tabular}

However, some of the above approaches are adequate for informal areas, but sometimes despite the efforts, some of them are not effective because they focus only on buildings, physical elements and other environmental problems without paying attention to other factors as social upgrading (capacity building, community empowerment and participation). Therefore, there is a demand for sustainable development or upgrading, which means developing many aspects as (physical, social, environmental), thus ensuring the continuous development, improvement and enhancing of the living conditions of the inhabitants, taking into consideration ( Saad, Fikry, \& Hasan, 2019).

\section{B. The Sustainable Slum Upgrading Rationale (on-site upgrading)}

Upgrading involves a package of improvements in the existing infrastructure, providing of the most basic services: i.e., water and sanitation, electricity, storm drainage, roads, footpaths, and often followed by other community facilities up to satisfactory standards. Upgrading also involve social and human development as health, education, or the enhancement of income opportunities through training programs besides citizen empowerment and building social capital. Moreover, environmental upgrading programs for solid waste collection are regularly included with its positive impact on removing environmental hazards.

The on-site slum upgrading is the most appropriate for dealing with coastal informal areas, as it has significant advantages over other approaches, because it keeps the social and economic bonds between dwellers by not moving them to new areas away from their work (coastlines) (Hamdi \& Goethert, 1997). In addition, the results of upgrading are efficient, immediate, improve the living conditions of the urban poor and make significant differences in the quality of life of them.

Involving the community within the upgrading process is an important factor because they know their living environment problems better than practitioners. Moreover, having their input and their help in decision-making will develop a sense of ownership and improve the project's opportunities for success. The involvement of all stakeholders as local governments, NGO's (Non-Governmental Organizations) and CBO's (Community-Based Organizations) could lead to sustainability by building self-sufficiency and capacity of the urban poor (Cronin \& Guthrie, 2011).

\section{Today's best-practice participation, participatory slum upgrading (The most sustainable approach in upgrading)}

Imparato and Ruster (2003) in their studies on slum upgrading and participation in Latin America, argued that participation is directly related to the nature of urban upgrading, particularly in slums. Moreover, imposing a participatory approach in upgrading projects helps to increase the project performance and enlarge the project sustainability (Imparato \& Ruster, 2003). At the core of any upgrading project are people's demands and needs which need to be clarified and prioritized; hence, there are the reasons for using participatory processes.

Enough evidence shows that participation have many benefits for sustainable development, if applied and maintained well. Participation promotes the sustainability of a project. A sustainable project permanently increases community's resources and decreases its vulnerability (Imparato \& Ruster, 2003). Thus, sustainability is the most appropriate action of the final success of a project. Involving people in the upgrading process of their own community gives them sense of ownership and satisfaction and enables them to make their own decisions and be responsible for them.

Moreover, community involvement with regards to slum upgrading has also economic benefits. It can generate economic benefits for entrepreneurs and semi-skilled and unskilled labor at the community level (Imparato \& Ruster, 2003). Finally, community participation in slum upgrading projects has also environmental benefits. Dwellers will accept such an upgrading project as their own responsibility and will do anything they can to maintain such project.

\section{Benefits and risks of participation (pros and cons):}

However, participatory approach has positive impacts in urban upgrading project, but there are risks and costs associated to participation are discussed as follows (Imparato $\&$ Ruster, 2003): TABLE 2 
TABLE 2

BENEFITS AND RISKS OF COMMUNITY PARTICIPATION, BY THE RESEARCHERS BASED ON (IMPARATO \& RUSTER, 2003)

\begin{tabular}{|c|c|}
\hline Benefits \& Outcomes & Disadvantages \\
\hline $\begin{array}{l}\text { Increasing the project's } \\
\text { sustainability through boosting } \\
\text { financial sustainability by } \\
\text { demand-responsiveness, } \\
\text { increasing social sustainability } \\
\text { through local ownerships, and } \\
\text { enhancing local people sense of } \\
\text { responsibility towards services } \\
\text { and facilities. }\end{array}$ & $\begin{array}{l}\text { The high costs of participation are } \\
\text { usually associated with the } \\
\text { expenses and time spent on } \\
\text { setting up the participatory } \\
\text { mechanisms, for instance; the } \\
\text { time required by staff team to } \\
\text { prepare the phases of the projects, } \\
\text { and the expenses for providing } \\
\text { social- technical services. }\end{array}$ \\
\hline $\begin{array}{l}\text { Participation enhances the project } \\
\text { effectiveness through providing } \\
\text { people's needs and increasing } \\
\text { access to local knowledge to } \\
\text { increase the solutions offered by } \\
\text { the project. }\end{array}$ & $\begin{array}{l}\text { Poorly managed initiatives of } \\
\text { participation without formalized } \\
\text { intervention or management may } \\
\text { paralyze the project. }\end{array}$ \\
\hline $\begin{array}{l}\text { Participation promotes goals such } \\
\text { as democratization, good } \\
\text { governance, and poverty } \\
\text { reduction through building } \\
\text { people's capacity and giving } \\
\text { them the opportunity in the } \\
\text { decision-making process to } \\
\text { change the actions that affect } \\
\text { their lives. }\end{array}$ & $\begin{array}{l}\text { Poor project management may } \\
\text { cause stakeholders frustration } \\
\text { due to delays, changes in } \\
\text { approach, or lack of information. } \\
\text { Indeed, this leads to loss of } \\
\text { credibility. }\end{array}$ \\
\hline $\begin{array}{l}\text { Participation through financial } \\
\text { contributions or community } \\
\text { labour can overcome resource } \\
\text { limitation. }\end{array}$ & $\begin{array}{l}\text { Political power or groups with } \\
\text { special interest may threat or } \\
\text { hijack the project. }\end{array}$ \\
\hline $\begin{array}{l}\text { Participation boots accountability } \\
\text { and transparency in the } \\
\text { supervision of public funds. }\end{array}$ & $\begin{array}{l}\text { Discussing problems that are } \\
\text { larger than the project's scope } \\
\text { may cause loss of focus towards } \\
\text { the project. }\end{array}$ \\
\hline
\end{tabular}

Thus, handling with coastal informal areas need to be done in collaboration with all community actors and stakeholders due to the unique cultural and social aspects of the community. Moreover, on-site upgrading projects are the most appropriate for sustainable upgrading to keep social ties, economic efficiency and no to tear down the community, as we will discuss in the following case studies.

\section{V.CASE STUDIES}

\section{Criteria for selection}

The selection of the case studies was determined by the following factors:

- Location: All selected case studies are coastal (waterfront) informal settlements whether sea, lake, or river, with an environmental connection to water.

- Urban Conditions: The areas selected are poor livelihoods with bad living conditions, and the characteristic of informal areas.

- Target Beneficiaries: The bulk of the population in the selected areas are working as fishermen or working on other related fishing businesses.

- The upgrading schemes: The upgrading strategies in all chosen neighborhoods are in-situ upgrading schemes.
- The structure of the programs: All the upgrading schemes for the case studies have not physical improvement component only, but also have social improvements to reduce vulnerabilities, promote social inclusion, and integrate these areas socially and spatially to the urban fabric. Moreover, the chosen upgrading schemes have the feasibility to achieve sustainable urban development depends on the equilibrium between social, economic and environmental factors.

- Participatory approach: The case studies were chosen for using participatory process as an approach to attain urban sustainability in coastal informal areas, where inhabitants are part of the upgrading process and not just the beneficiaries of the development project.

\section{Criteria For analysis}

- The framework used for analysis of the case studies was generated from the components of the upgrading schemes and its relation to sustainable urban development, considering economic efficiency, environmental protection, human wellbeing and social equity.

- The analysis is based on the similarities between the upgrading schemes in different governmental and cultural contexts at coastal settlements, and the outcomes of the upgrading schemes were organized according to participation and sustainable upgrading. Figure. 4

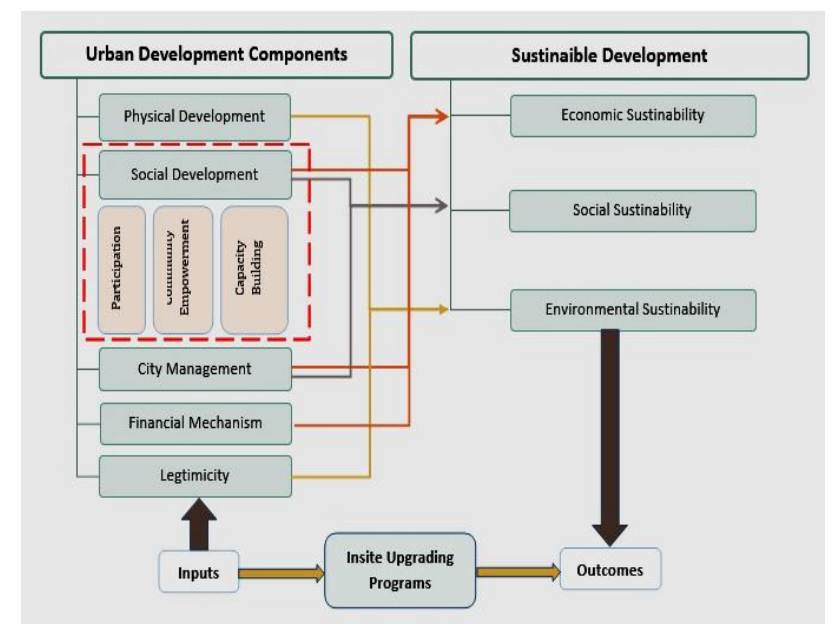

Figure.4: Criteria for analysis based on relation between concepts by the researchers.

\section{A. The KOTAKU -Kota Tanpa Kumuh-Program (City Without Slums), Indonesia}

Indonesia is still suffering from informal settlements until nowadays (Dianingrum, Faqih, \& Septanti , 2017). The word Kampung is the one used to depict the informal settlements in Indonesia. These Kampungs have transformed from small villages and inhabited by low-income dwellers with less urban services (Dianingrum, Faqih, \& Septanti , 2017). 
Location: Sukolilo District, Bulak subdistrict, Surabaya, Indonesia

Surabaya is the second biggest city in Indonesia, which is in East Java Province (Shirleyana \& Anindya Sari, 2012), and with a population around 3,09 million people (Septanaya, Rahmawati, Navitas, \& Stefanugroho, 2020). It is also considered as a coastal city with kampungs located on the eastern coastal line. One of the coastal slums located in Surabaya City is Sukolilo District, Bulak Subdistrict. Figure.5 It is a fisherman settlement and a center for marine and seafood products processing marketed in various regions in Indonesia ( Fajrin , Faqih, \& Septanti, 2018). Figure.6

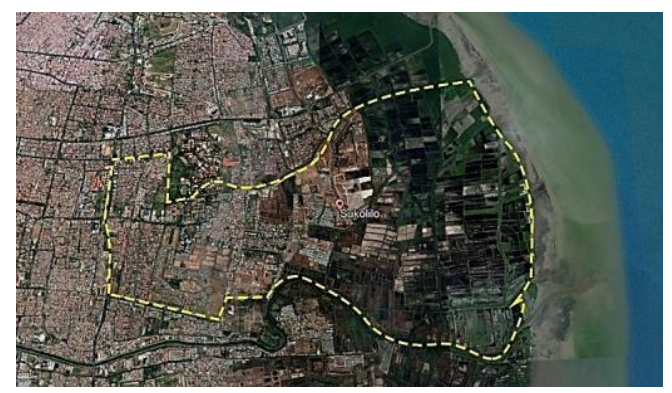

Figure.5: Map of location study, by the researchers modified from Google Map 2021.

\section{Framework for the KOTAKU Program (City Without Slums)}

The main theme of this programs is the "100-0-100 Movement" for achieving a friendly and comfortable environment for the community. The target tends to provide $100 \%$ access to safe drinking water, $0 \%$ slums, and $100 \%$ access to adequate sanitation (Sari, Suman, \& Kaluge, 2018). The program is carried out through participatory approach and involving the community, local government, non- governmental organizations, and other stakeholders (Kotaku Program, 2017).
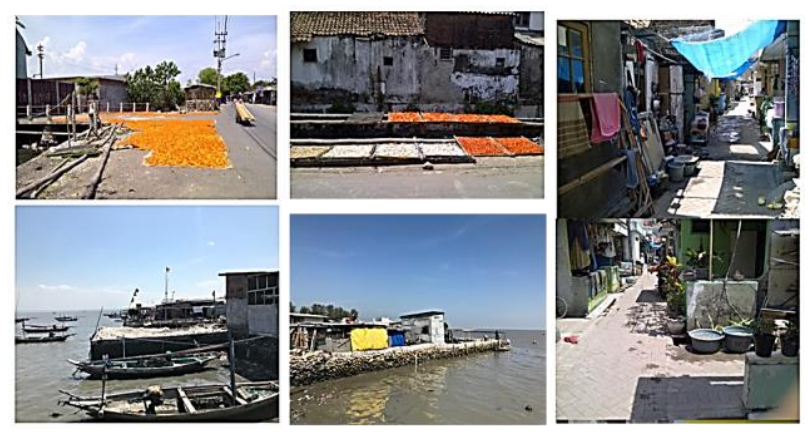

Figure.6: The existing conditions of the coastal informal Sukolilo District, Bulak subdistrict, Surabaya, Indonesia (Wardhani D. K., 2017) \& (Fajrin, Faqih, \& Septanti, 2018).

\section{A. Scope}

The general aim of KOTAKU Program is to provide a decent life for all slums citizens in Indonesian cities (Cheema, 2020) and develop human resources economically and socially to enhance community welfare (Rohimat, Rahmawat, \&
Seran, 2018). The program also tackles the needs for social and human development (Zain, Salman, \& Baja, 2018).

\section{B. Objectives}

The KOTAKU Program is a community empowerment approach, so its implementation mainly depends on the active participation of the community at all development stages (Alamsyah \& Jamil, 2020). This is carried out through the following activities:

- Partnerships between community, local government, and private sector (Alamsyah \& Jamil, 2020).

- Strengthening the capacity of the community and the institutional capacity of the local government as well (Alamsyah \& Jamil, 2020).

- Enhance the community livelihood based on physical, social characteristics (Kotaku Program, 2017).

\section{C.Program Components}

- Physical Upgrading: Improving the roads network and enhancing the poor quality of roads. Moreover, Community Self-Reliance Agencies (BKM) have done several activities as providing paving blocks, installing of U-Ditch precast and providing of motorized garbage carts (Septanaya, Rahmawati, Navitas, \& Stefanugroho, 2020). Improving wastewater infrastructure and constructing stations for waste processing. Developing the drainage services and constructing drainage channels connected to the city. The municipal government has built bridges, inspection roads and sea embankment in Sukolilo district to minimize the risk of floods (Kotaku Program, 2017).

- Social Development: It is observed that the KOTAKU program upgrades the physical environment and enhances the social and economic aspects. The program also represents a platform for the involvement of all community groups, especially women in management and implementation activities of the program (Alamsyah \& Jamil, 2020). Hence, KOTAKU Program encourages social inclusion through integrating all community groups. Moreover, the program empowers inhabitants through enabling them to participate in every step in the upgrading program. The citizens' participation in all stages and also extends to the maintenance phase to ensure the program's continuity. Another form of community involvement in the program was the community contribution in the project's funding, about $20 \%$ of the total funds, in the form of workforce or cash. Throughout the project, the Community Self-Reliance Agencies (BKM) in Sukolilo have implemented economic programs in the form of community empowerment trainings and workshops. These workshops enhanced fishermen's skills in the processing, packing, and marketing of fish products. These workshops can greatly 
contribute to the capacity building of citizens, empower them, and increase their productivity and average income (Septanaya, Rahmawati, Navitas, \& Stefanugroho, 2020).

- Legitimacy: The program did not target kampungs with illegal land ownership, and that is because the government avoid the failure of the upgrading program due to land conflict between residents and government (Septanaya, Rahmawati, Navitas, \& Stefanugroho, 2020).

- Project Management: Organizations as; Community Selfhelp Organization (BKM), Community Self-Help Group (KSM) and Community Self-Help Institution (LKM) were requested to frame a Neighborhood Upgrading Action Plan (Rencana Penataan Lingkungan Permukiman/ RPLP), with a duration of 5 years. The RPLP document was supervised by government representative at the district and subdistrict level, and KOTAKU facilitator team. The RPLP consists of economic, social, environmental plans, maintenance and operational physical plan, and budgeting plan to be given access to the investment's funds of KOTAKU. After finishing all RPLP documents, Housing and Settlement Working Group (Pokja-PKP) evaluates the document's contents to check if they meet the program's objectives. Then, all documents were submitted to the government of Surabaya through to obtain approval and legalization (Septanaya, Rahmawati, Navitas, \& Stefanugroho, 2020).

- Financing Mechanism: The KOTAKU Program is a collaborative platform financed by multiple actors (Yopiannor \& Wibowo, 2019) as, central government, provincial governments, district / city governments, nongovernment organizations (Septanaya, Rahmawati, Navitas, \& Stefanugroho, 2020) and overseas international organizations as World Bank, Islamic Development Bank, and the Asian Infrastructure Investment Bank (Rohimat, Rahmawat, \& Seran, 2018). According to (Kotaku Program, 2017), the total financing from the international partners (loans) are about $45 \%$. Moreover, the inhabitants were requested to pay about $20 \%$ the total cost of the program as a community contribution in the form of cash or workforce (Septanaya, Rahmawati, Navitas, \& Stefanugroho, 2020).
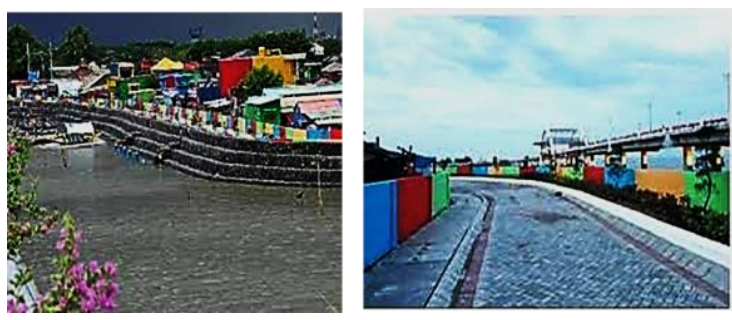

Figure 7: Sea walls, drainage cannels and paved roads successfully built by the KSM in Sukolilo Baru Subdistrict in 2016, (Septanaya, Rahmawati, Navitas, \& Stefanugroho, 2020).

\section{Sustainable Outcomes}

\section{Economic Sustainability}

- Using collaborative funding from multiple sources; as the community was requested to pay $20 \%$ of the funding in terms of cash or workforces.

- Establishing the financial management unit at BKM to manage Investment Fund Aid (BDI).

-Increasing person's income through training workshops.

- Increasing community-livelihood welfare and economic development through small-scale business and Business Development Center (BDC).

- Establishing the User and Maintenance group (KPP) to guarantee fund-raising for the maintenance operations of the built infrastructure to gurantee the program's sustainability.

- Giving access for the inhabitants to financial services through micro loans.

\section{Environmental Sustainability}

-Enhancing the quality of the urban environment through providing infrastructure and urban services.

- Bringing up the function of green open spaces as a sustainable livelihood for citizens.

- Launching socialization events for cleaning the environment, such as waste management, raise awareness and change dangerous environmental habits as throwing litter on seashores, vacant land and drainages.

- The management and maintenance operations for the built environment through the User and Maintenance group (KPP) to ensure the environmental sustainability of the project.

\section{Social Sustainability}

\section{- Empowerment}

- Integrating the urban poor into the formal urban of the city, and Reducing vulnerabilities by including vulnerable groups in the decision-making process.

- Empowering women trough allowing them to participate in the BKM management board.

- launching economic programs as community empowerment workshopsn and training sessions to enhnace thier marketing skill lessons in fish products industry.

-Encouraging community initiatives for physical and social development.

- Mobilizing people resources and workforces in upgrading the built environment.

\section{- Community Capacity Building}

- Strengthen the community capacity by encouraging the role of community self-help organizations (BKM).

- Allowing ctizens to participate in the upgrading program, and formulating the Neighborhood Upgrading Action Plan (RPLP), including economic, social, environmental plans, maintenance and operational physical plan, and budgeting plan.

- Community participation in the funding or by physical workforces.

- Social Capital

- Providing social services as, health and education.

- encouragin collaboration between various stakeholders to develop institutional capacities for organizations.

- Encourage home- based small business especially for women.

- Community represented in BKM managed to control management of investment funds.

Figure.8: shows chart of the sustainable outcomes of the KOTAKU Program, by the researchers. 


\section{E. Drivers extracted for the proposed framework}

\begin{tabular}{l}
\hline Collaborative funding \\
\hline Funds for managment \\
\hline Acessability \\
\hline Building community capacity \\
\hline Social capital and community participation \\
\hline Building capacities of local governmnet \\
\hline Collaboration between all stakeholders \\
\hline Creating employment opportunities \\
\hline Incresing productivity \\
\hline Encourage small-based industries \\
\hline Waste managmnet \\
\hline Providing green open spaces \\
\hline Encourage related fishing industries \\
\hline Decentralization \\
\hline Community empowerment \\
\hline Physical improvement for the built environment \\
\hline Committee for monitoring and evaluation the implementation \\
\hline
\end{tabular}

\section{F. The Lagos Metropolitan Development and Governance Project (LMDGP), Nigeria}

Although Nigeria has been known for its economic growth as the largest informal sector in Africa, the bulk of the population is living in extremely deprived conditions (Ajayi, Oviasogie, Azuh, \& Duruji, 2014). The country suffers from several challenges as; high urbanization in slums (estimated at about $69 \%$ ), land tenure conflicts, poor infrastructure, and lack of basic urban services (UN-Habitat, 2020).

Location: Makoko, Lagos, Nigeria

Lagos is situated at the South-Western of Nigeria (Oyinloye, Olamiju, \& Popoola, 2017), and acts as the country's main commercial center. It is considered as the second fastest growing urban center in Africa after Cairo (Aluko, 2010). This high population growth has led to urban degradation and unusual demand for land. Therefore, Lagos has formed overcrowded slums which lack of basic services in many areas, including Makoko (Adelekan, 2010). Figure.9

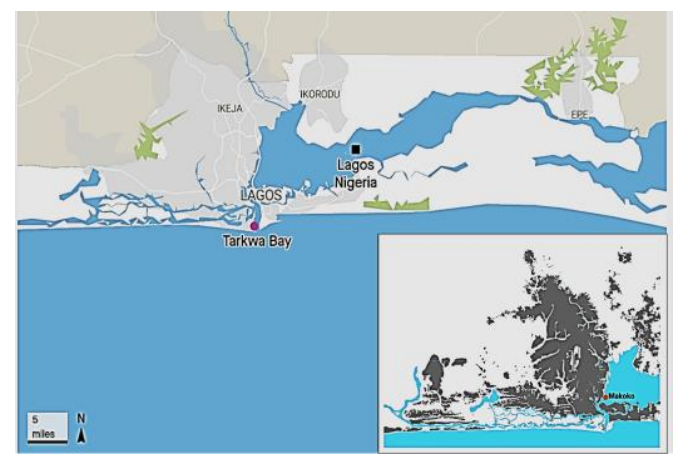

Figure.9: Shows the location of Makoko within the Lagos Local Government, modified from Open Street Maps 2021 \& (Hoelzel, Ummuna, \& Morka, 2014).
Makoko is one of the waterfront slum settlements built along the coastal area of Lagos. It is a central part of the Lagos community in terms of its overcrowded population, and its economic importance to the Lagos state (Oyinloye, Olamiju, $\&$ Popoola, 2017). The major economic activity of Makoko residents includes fishing, salt making and trading. The community lacks basic infrastructure and urban services (UdoUdoma, 2014). Figure.10.

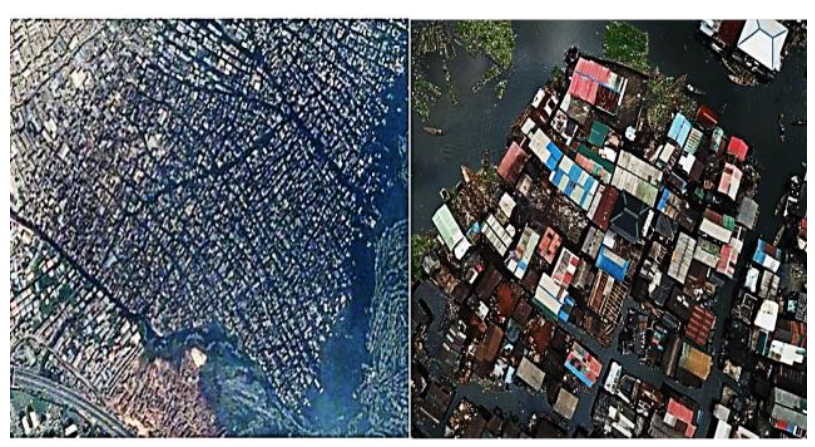

Figure.10: An arial photograph of Makoko floating slums, (Oyinloye, Olamiju, \& Popoola, 2017).

\section{Framework for The Lagos Metropolitan Development and Governance Project (LMDGP)}

The Lagos Metropolitan Development and Governance Project (LMDGP) was launched in 2007 by the World Bank with a loan up to two hundred million US dollars (Adama, 2020). The project comprises of four components; infrastructure; public governance, capacity building and urban policy. Nine major slums were selected for the upgrading by the LMDGP, including Makoko. The World Bank identified water, sanitation, education, health facilities, roads, drainage, markets, community recreation facilities as the necessary infrastructure needs (Udo-Udoma, 2014). Community participation and sustainability are crucial elements of the LMDGP, so the project would continue beyond the project's period of five years (Hoelzel, Akinsete, \& Partner, 2015).

\section{A. Scope}

The general aim of the LMDGP is to transform Lagos into a world-class city and make the city more attractive and tourism-friendly through private investments, community development and a sustainable regeneration plan (Hoelzel, Akinsete, \& Partner, 2015).

\section{B. Objectives}

The LMDGP principles were (Udo-Udoma, 2014):

1. Improve the living conditions of the inhabitants through infrastructural upgrades. 
2. Capacity building, institutional and governance development for urban management of slums.

3. Adopting community participation as a central principle in the upgrading interventions.

4. Cooperation between the local government bodies, community organizations and sponsors in improving slums, including Makoko.

\section{Program Components}

- Physical Upgrading: The LMDGP has constructed neighborhood hotpots to deliver infrastructure services daily at local levels to provide benefits for all dwellers (Hoelzel, Akinsete, \& Partner, 2015). The energy hotspot works as a center for producing renewable energy from waste management, biogas planet, grassroot for healthcare delivery, water harvesting and urban gardening (Akinsete, Hoelzel, \& Oshodi, 2014). Figure.11. Besides, the rehabilitation of roads and providing street lighting system depending on solar power. Moreover, the LMDGP managed to renovate four schools and transform the market from a waste dump to a new spot for fishermen to sell their products.

- Social Development: The project highlighted the importance of community participation to attain the sustainability of the project and allocated the total of USD 1.25 million for Social Sustainability Program (Adama, 2020). Community inclusion was the core elements of the LMDGP, with a collaboration between three main stakeholders (Lagos government, Makoko's community and LMDG / World Bank). The project managed to achieve community empowerment, because community dwellers came together to make decisions related to the upgrading projects. Moreover, several upgrading projects were implemented by and for the residents, such as, The Asejere Market in Makoko. The market project is an example of how the community could take control and manage a project. The community took a full control of the project and worked together to raise a structure roof to protect them from the weather (Udo-Udoma, 2014). Moreover, the construction of the neighborhood hotspot is an evidence that the LMDGP has interested in building local capacity, as local citizens were engaged in the construction process. Furthermore, the place is mainly for social exchange, business incubator and social infrastructure for empowering the community (Hoelzel, Akinsete, \& Partner, 2015).
- Legitimacy: There was a promise by the LMDGP that there would be no evictions, and if it were unavoidable there would be a short-term only in exceptional cases and dwellers should be compensated financially. Though, Makoko residents were given a 72-hour eviction notice to evacuate illegal structures on 12 July 2012. After that, a demolition action was done on some structure on the waterfront in Makoko (Hoelzel, Akinsete, \& Partner, 2015). However, no compensation was made for the community members, and this led to public protests and a court order to stop the demolitions (Adama, 2020).

- Project Management: The Lagos government has elaborated a structure to manage dialogue between different stakeholders as civil society, NGOs, local government officials, World Bank staff, private sector, and the community (Adama, 2020). Therefore, The Lagos State Urban Renewal Authority (LASURA) worked to set guides, facilitate and support the implementation of the LMDGP. Moreover, the LMDGP has established the Project Coordination Unit (PCU) which was funded by the World Bank and responsible for the four stages of the LMDGP (Hoelzel, Akinsete, \& Partner, 2015).

- Financing Mechanism: The LMDGP was funded by the World Bank, after the Lagos government has proposed the project's framework to get a loan up to two hundred million US dollars (Adama, 2020). However, the project's fund was from an international organization, but there were attempts of inhabitants' contributions in the investment fund. To elucidate, the women traders in Makoko community started a saving group together to invest in their trades. Every woman contributed by 100 Naira (US\$ 0.8) weekly to save enough money to get a loan from SERAC (the only NGO exists in Makoko).

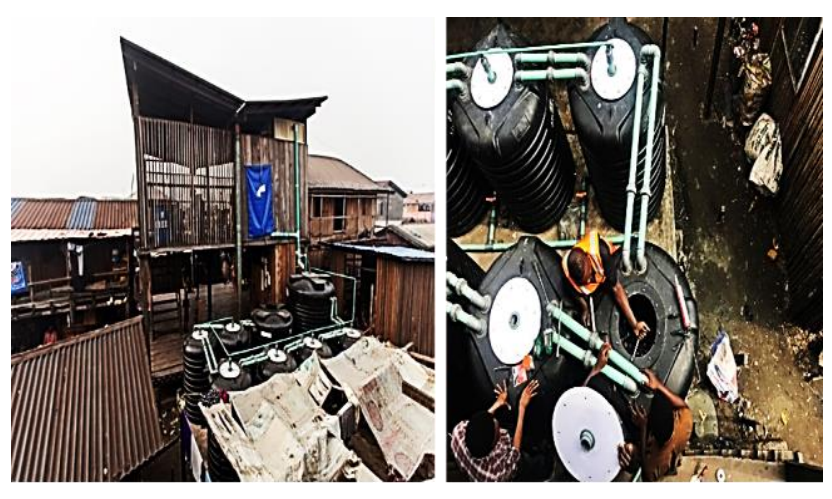

Figure.11: The Makoko Neighborhood Hotspot, (Hoelzel, Ummuna, \& Morka, 2014). 


\section{Sustainable Outcomes}

\section{Economic Sustainability}

- Renovating the Asejere market to be the center of the economic development for Makoko. The market has become the main spot for fishermen to sell their products.

- Enhancing the economic growth and the inhabitants' income after upgrading the market.

- Encouraged women to work in house-based industries and enhance their income.

- Attracting private investments to offer more loans for the market's traders.

- The neighborhood hotspot is a business incubator and a place for economic potential benefits from renewable energy production, and micro-business opportunities for a resource-based economy.

- Some women started a saving group to get a loan from SERAC the NGO as a micro-finance scheme to invest more in their productive house-based industries and enhance their financial situation.

\section{Environmental Sustainability}

- Delivering infrastructure as water, sanitation, and drainage to provide a healthy and sustainable environment.

- Improving waste management services through constructing new solid waste management stations.

- Solveing the concerning environmental challenge as waste management by constructing the neighborhood hotspot as a biogas station generating energy from organic waste.

- Integrate other sustinable activities in the neighborhood hotspot as urban gardening, renewable energy production and water harvesting.

- Using sustainable local resources and eco-friendly materials in building the neighborhood hotspot and schools.

- Constructing of innovative and sustainable buildings, the floating school as a movable watercraft at the center of the Makoko floating community.

\section{Social Sustainability}

\section{- Empowerment}

- Empowering women through the market women association to authorize the market and control prices.

- Increasing equity and equality between genders through giving women the chance to sell their fish and benefited from the market.

- Recongnition of the Makoko community leaders by the Lagos government, has empowered them to provide infrastructure developments to thier community.

- Providing job opportunities through neighborhood hotspot as residents work in renewable energy production, urban gardening, water harvesting and waste management.

- Encouraging community initiatives as garbage collection.

- Community Capacity Building

- Building capacities of youth through employing them in constructions work.

- Building women capacity through giving them the charge of the Asejere market through the market women association.

- Giving residents the responsibility of the maintenance stage, and technicians will interfer if it required.

- Encouraging social activities through providing green spaces and workspaces.

- Community participation was limited in the decision-making process, but local youth and community leaders were included in MCDA to supervise the construction and maintenance phases

- Social Capital

- Providing social services as, health and education.

- Enabling community orgaizatins as the Makoko Community Development Association (MCDA), to be responsible for the maintenance of roads and public spaces in the community.

- Encouraging small business form women through their saving group.

- Providing community center in theneighborhood hotspot to incorporate various activities with providing space for social exchange as community empowering infrastructure.

- Enabling micro-business opportunities for a resource-based economy as the neighborhood hotspot.

- Organizing training sessions and educational programs for Makoko dwellers by NGOs, that integrated community participation, housing, health, and women rights issues

Figure.12: shows chart of the sustainable outcomes of the LMDGP, by the researchers.

\section{E. Drivers extracted for the Proposed Framework}

\begin{tabular}{l}
\hline Preserve coastal charactristics \\
\hline Connecting the informal to the formal \\
\hline Mobility \\
\hline Physical improvement for the built environment \\
\hline Providing fishing industries facilities \\
\hline Community empowerment \\
\hline Building community capacity \\
\hline Collaborative funding \\
\hline Funds for managment \\
\hline Social capital \\
\hline community participation \\
\hline Providing community needs \\
\hline Providing social services \\
\hline Resilience structures and materials \\
\hline Sustinable resources \& recycling \\
\hline Building capacities of local governmnet \\
\hline Community committee for maitenance \\
\hline Creating employment opportunities \\
\hline Attracting foreign investments \\
\hline Self employment skills \\
\hline Waste managmnet \\
\hline Providing green open spaces \\
\hline Green infrastructure and renewable energy \\
\hline Providing training sessions for vulnerable groups \\
\hline Collective business groups for small families \\
\hline
\end{tabular}

\section{B. Participatory slum upgrading Project in Ezbet EL Bahtini,} Ismailia (PSU)

The United Nations Development Program (UNDP) with support from UN-HABITAT started a capacity building project called "Sustainable Ismailia Governorate" to develop the city profile with themes of urban upgrading, industry, agriculture and Lake Timsah pollution (Ismailia, 2005). The project contributed to poverty reduction through empowering women and community organizations. As a continuous to the urban upgrading activities a request was presented to the UN HABITAT and the World Bank to fund the upgrading of informal settlements on the Lake Timsah: El Bahatni and El Hallous (Habitat, 2015). Figure.13

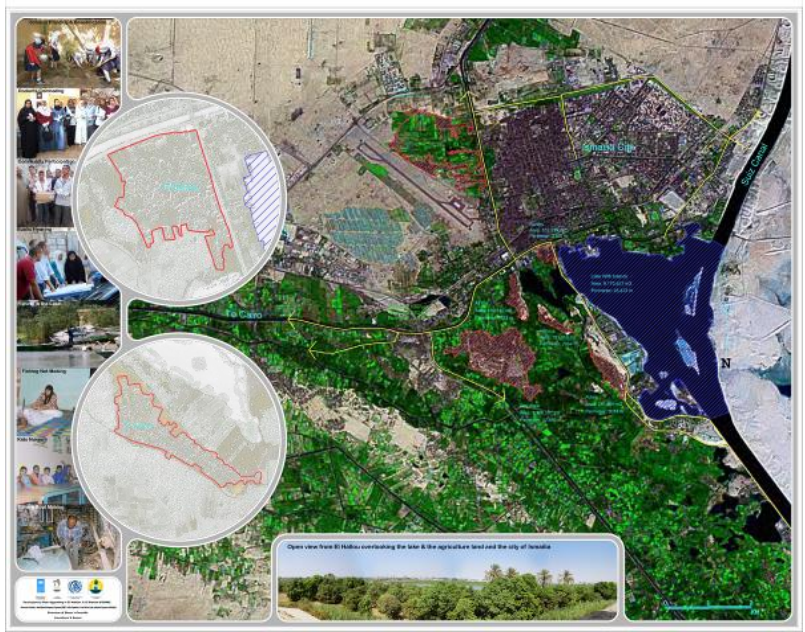

Figure.13: Location of Hallous and EL Bahtini (El Hefnawi, 2008). 


\section{Location: Ezbet EL Bahtini, Ismailia Governorate, Egypt}

According to Ismailia (2005), Ezbet El Bahtini area is nearly 16 hectares with a population of 7000 and about $30 \%$ of the population are vulnerable (women, children and elderly). The urban profile of the area is damaged and is considered as a coastal informal settlement with severe economic, environmental and social problems. The pollution in the Timsah Lake has affected many inhabitants who depend on fishing activities (UNDP, 2011). Therefore, the purpose from the project is to develop the slum of El Bahtini through a participatory (HABITAT, 2010).

\section{A. Scope}

The PSU's main aim is to enhance the living conditions of the inhabitants of El Bahtini and El Hallous in Ismailia through providing a participatory upgrading approach. The project focused on three components physical upgrading, social upgrading and capacity building. The physical component included providing basic urban infrastructure such as drinking water, drainage network, paved roads and electricity cables. While the social component comprised of providing literacy classes, health awareness campaigns, supplying equipment to youth centers, issuing cards for women, and solving land tenure problems. As for capacity building, the program aimed to help local authorities in upgrading activities and inhabitants by providing micro-loan programs in cooperation with a local NGO (Habitat, 2015).

\section{B. Objectives}

The main objectives of the PSU (euromedina.org, 2015):

- Providing basic physical infrastructure for enhancing the living environment.

- Increasing the social capital of the inhabitants.

- Building capacities of local authorities and communities in participatory local governance through establishing working groups and providing training programs for authorities and community members.

\section{C.Program Components}

- Physical Upgrading: Providing and enhancing basic urban infrastructure such as drinking water, drainage network, paved roads and electricity cables (El Hefnawi, 2008). Figure.14

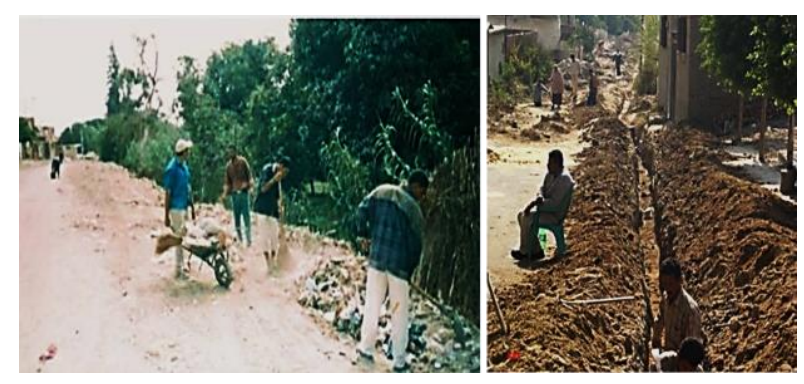

Figure.14: Physical upgrading of EL Bahtini (UNDP, 2011).
- Social Development: Enhancing the socio-economic standards of inhabitants and vulnerable groups such as women, children and elderly, and this includes activities as (Habitat, 2015):

- Organizing illiteracy eradication classes.

- Initiating health awareness campaigns for fishermen, women and students.

- Providing the micro-loan programs in cooperation with a local NGO.

Moreover, the PSU implemented a participatory approach and urban upgrading activities as follows (El Hefnawi, 2008):

- Providing training in management for 25 local trainees in collaboration with UN-Habitat, beside GIS training.

- Providing three-phase program for government workers in the housing development departments to enhance their capacities.

- Three informing workshops were given for local authorities and communities about the participatory planning approach for upgrading slums.

- Using the work group approach in the upgrading activities has enabled more participation for all stakeholders. Figure.15.
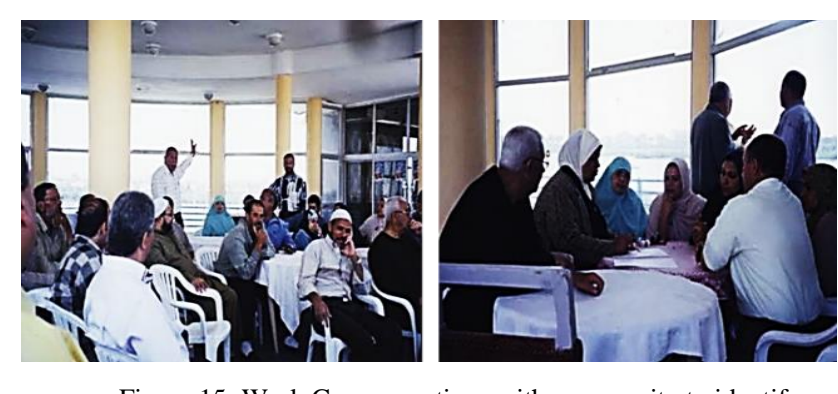

Figure.15: Work Group meetings with community to identify social needs (UNDP, 2011).

- Legitimacy: There was no problems of land tnure within the area.

- Project Management: The project was formed from a partnership between the Italian government and the local governorate of Ismailia, besides international organizations as UNDP and UN-HABITAT (HABITAT, 2010). Moreover, a local organization ADE (Association for Development and Environment) and other CBOs were participants in the project (Habitat, 2015). The PSU project was executed by the Ismailia Governorate at the national level under the supervision of the United Nations Development Program (UNDP) through the national execution modality (UNDP, 2011). A High-Level Committee for Participatory Slum Upgrading was established to coordinate the project and was headed by the Ismailia's governor. It was responsible for coordinating between all local authorities who are the main actors in the project. Moreover, starting the Technical Advisory Unit (TAU) which is responsible for delivering reports to Ismailia's governor, besides day-to-day management 
through the National Project Coordinator (UNDP, 2011). The PSU also created Working Groups (WGs) To achieve the concept of participatory slum upgrading, as they composed of a range of stakeholders (Habitat, 2015). They were set up to prioritize needs, identify issues, and act as communication channels between local authorities and the community (euromedina.org, 2015). Finally, Implementation Units (IUs) were established in each of the two slum areas to supervise the daily work on the physical and infrastructure component of the project.

- Financing Mechanism: The total budget of the project was estimated by US $\$ 4.8$ million through a bilateral debt swap for the Egyptian Government by the Italian Government for the upgrading projects in El Bahtini and El Hallous (Habitat, 2015).

\section{Sustainable Outcomes}

\section{Economic Sustainability}

- Providing micro-loans from the Central Government for literacy classes, health centers and vocational training.

- Cleaning of El Temsah Lake has increased fish and fishermen's catch, and that affected thier daily income.

\section{Environmental Sustainability}

- Enhancing the quality of the urban environment through providing infrastructure and urban services.

- Cleaning El Temsah Lake.

- The project constructed CBOs to gurantee the continuty of the project after upgrading and to supervise the maintenance works.

\section{Social Sustainability}

\section{- Empowerment}

- Providing small loans funded by the Ministry of Social Solidarity and vocational training sessions for women to generate income activities.

- The project used a strong gender aware approach and managed to target other vulnerable groups including old people and fishermen.

- The project succussed to work with various stakeholders and NGOs and allowed the community to participate in the upgrading process, giving them the potential of building capacities and project's sustainability.

- Providing training sessions for local authorities' staff in urban development.

- Allowing volunteers to participate in various project activities as, monitoring the workflow of service providers and awareness campaigns concerning women and youth

- Community Capacity Building

- The project managed to institutionalize the participatory slum upgrading approach within the government's framework.

- The Sustainable Ismailia Training Centre in the project managed to build capacities of local governemnt's staff.

- Using Working Groups for project coordination and management.

- Social Capital

- Providing social services as, health and education on small scale, but it responded to identified demands of the community.

- Encouragin collaboration between various stakeholders to develop institutional capacities for organizations.

- Launching two Implementing Units to report any problems or demands of the community to the project management board.

Figure.16: shows chart of the sustainable outcomes of the Participatory slum upgrading Project in Ezbet EL Bahtini, Ismailia (PSU).

\section{E. Drivers Extracted for the Proposed Framework}

\begin{tabular}{l}
\hline Participatory budget from taxes or workforces \\
\hline Funds for managment \\
\hline Physical improvement for the built environment \\
\hline Building community capacity \\
\hline Community empowerment \\
\hline Social capital \\
\hline Community participation \\
\hline Social cohesion \\
\hline Civil scoiety organizations role \\
\hline Women empowerment \\
\hline Providing social services \\
\hline Educational \& health facilities \\
\hline Limit pollution \\
\hline Cleaning water bodies \\
\hline Participation in the descision-making process \\
\hline Strengthen institutional capacities \\
\hline Building capacities of local governmnet \\
\hline Participatory polices \\
\hline Community committee for maintenance \\
\hline Collaboration between all stakeholders \\
\hline Involvment of community in different stages \\
\hline Reinforcment of local institutions \\
\hline Creating employment opportunities \\
\hline Incresing productivity \\
\hline Encourage small-based industries \\
\hline Skill training \\
\hline Collective business groups for small families \\
\hline Providing credits for small businesses \\
\hline
\end{tabular}

Comparing the case studies based on the three dimensions of sustinabiity according to a number of aspects etxtracted from various literature review as ( Saad, Fikry, \& Hasan, 2019), (Hassan, 2012), (Judd \& Adams, 2016), (Dewi, Santosa, \& Defiana, 2015), and (Restrepo Rico, 2017). The comparison (Figure.17) in the form of a checklist to estimate if the upgrading schemes in the previous caes studies managed to achieve the aspects of sustainability or not.

\section{CONCLUSION}

Finally, the research concludes that:

- Respecting the coastal characteristics of coastal settlements through building capacities of fishermen and empowering them through training workshops to develop their marketing skills and processing fish products. Moreover, encouraging small home-based industries helps in empowering women in coastal informal areas. 
- Community participation is essential step to guarantee the inhabitants' satisfaction and meet their demands as a corner stone for achieving sustainability in coastal informal areas.

- Using collaborative funding from various stakeholders enhances the participation process and increases decentralization.

- During the construction process, some mistakes could appear due to the lack of skill and experience for volunteered citizens. Thus, absorbing the community into the participatory approach without any specific requirements or training is not sustainable on the long term regarding the economic sustainability.

- The outcomes of the maintenance stage could be inefficient and unsustainable due to the lack of funding for infrastructure management after the project ends.
- Humans could be a weak factor in the upgrading process for the misuse or misconduct of funds by some citizens.

- It is unsatisfactory approach to relocate dwellers of coastal informal areas away from their place for upgrading purposes, as they are connected to their workplace and the social ties between them.

- Addressing land tenure and legitimacy problems by upgrading projects in important to resolve conflicts between residents and the government due to the land use and the high value of lands.

- Conflicting decisions from different government authorities and stakeholders resulted in delays for the upgrading process.

- Encouraging investment through providing small loans for dwellers helped in increasing the economic local level of the community.

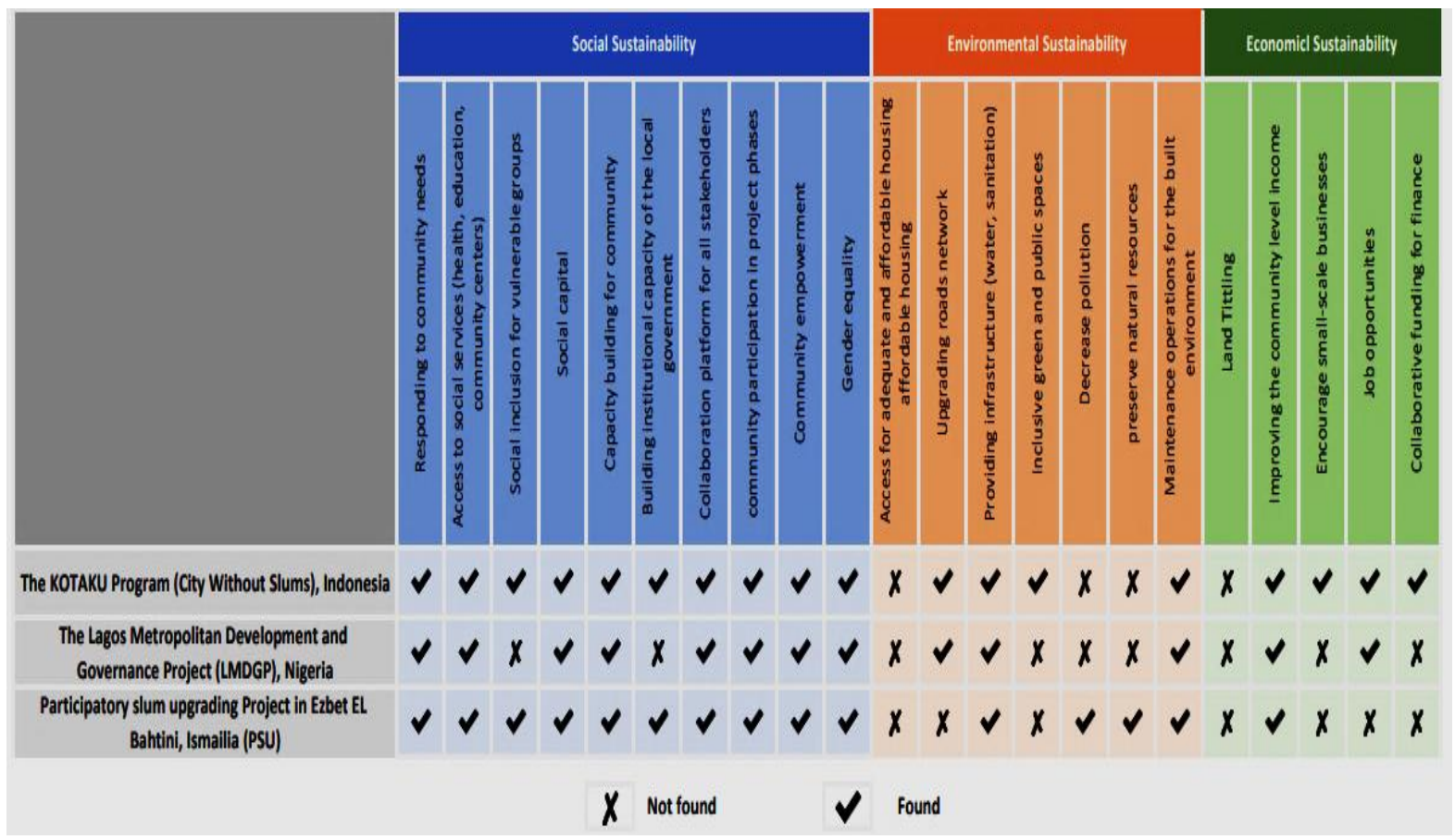

Figure.17 : Comparison between the case studies in terms of achieving sustainability, by the researchers.

\section{RECOMMENDATIONS}

According to the conclusion above and the analysis of the previous case studies, the research recommends the following framework for achieving sustainable urban development in thecoastal informal areas in Egypt. The guidelines extracted from the analysis of the previous case studies-besides two other cases studies in El Sackalla district, Hurghada, Red Sea Governorate and Al Qursayah, Giza Governorate in Egyptwere used to formulate the proposed framework (Figure.18), the proposed framework may include other adaptions when further fieldwork is allowed ${ }^{2}$.

2 The authors analyzed two more coastal cases studies besides the mentioned in the paper (El Sackalla district, Hurghada, Red Sea Governorate and Al Qursayah, Giza Governorate in Egypt), in addition to theoretical study and urban inspections of Ezbet Al Burj city in Damietta Governorate in Egypt as an example of coastal informal area. Moreover, this framework was tested through questionnaires, interviews with various stakeholders, and urban documentation by $15 / 9 / 2021$. The framework may have other adaptions when more field work is done according to the current situation of the specific coastal informal area. 


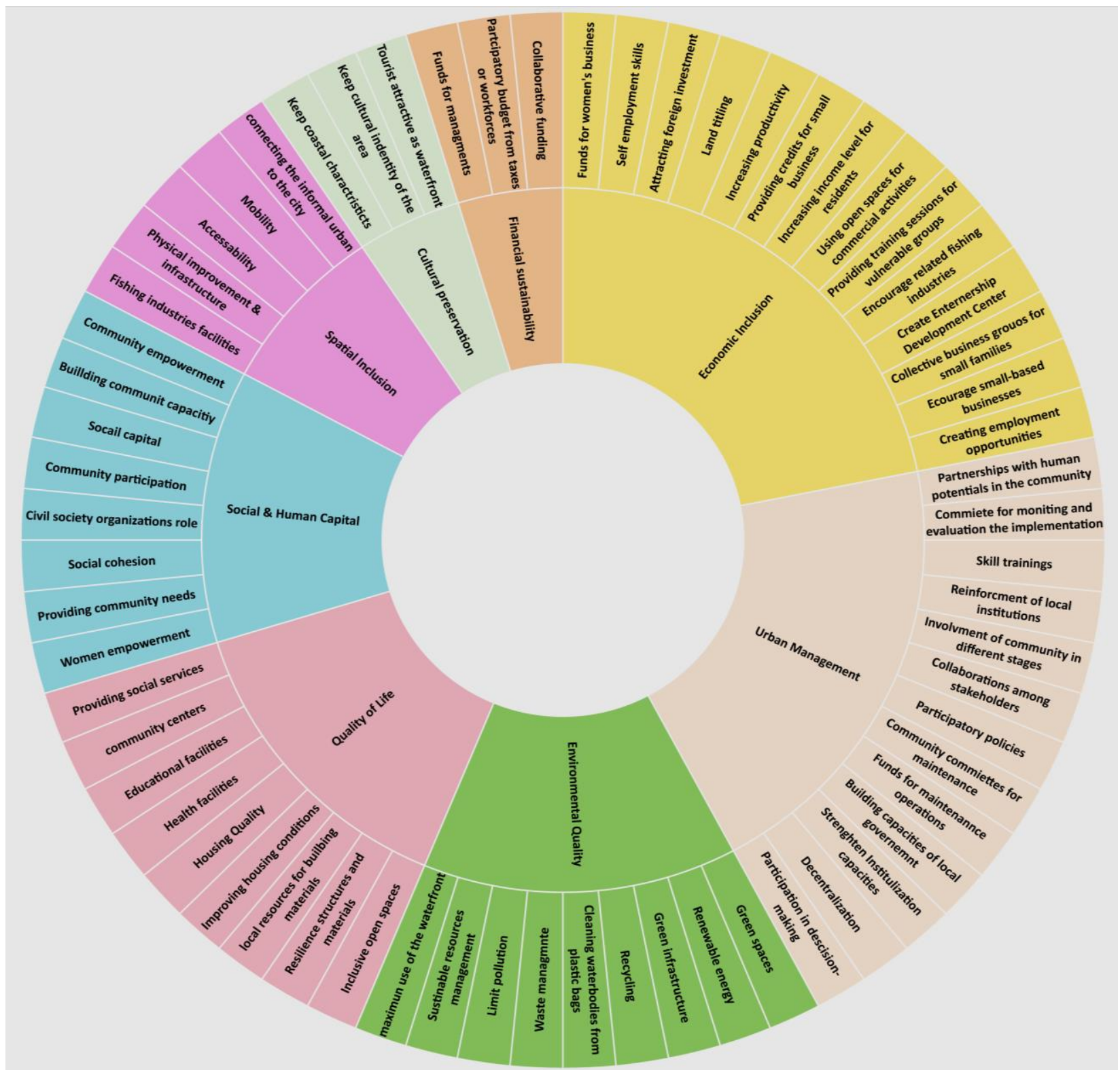

Figure.18: Framework for sustainable urban development in coastal informal areas in Egypt, by the researchers.

\section{AUTHORS CONTRIBUTION}

\section{Reem Kamel Elnady,}

1- Conception and design of the work.

2- Data collection and tools.

3- Data analysis and interpretation.

4- Methodology.

5- Drafting the article.

6- Final approval of the version to be published.

\section{Alaa Shams and Nasr El-din Elbadrawey,}

1- Conception of the work.

2- Methodology.

3- Supervision.

4- Critical revision of the article.
I confirm the following:

- The corresponding author is responsible for ensuring that the descriptions are accurate and agreed by all authors.

\section{FUNDING STATEMENT:}

The author did not receive any financial support of the research authorship and publication of this article

\section{DECLARATION OF CONFLICTING INTERESTS STATEMENT:}

The author declared that there are no potential conflicts of interest with respect to the research authorship or publication of this article 


\section{REFERENCES}

[1] Fajrin , A., Faqih, M., \& Septanti, D. (2018). Revitalization Strategy of Sukolilo Baru Coastal Settlement. International Journal of Engineering and Techniques, 4(4), 62-71. Retrieved from http://www.ijetjournal.org

[2] Rolalisasi, A., Soemarno, I., \& Ariastita, P. (2009). Slum Upgrading through community participation. Informal Settlements and Affordable Housing 2009

[3] Saad, O., Fikry, M., \& Hasan, A.-S. (2019). Sustainable upgrading for informal areas. Alexandria Engineering Journal.

[4] A. Ghoneim, S., B. Salem, R., \& Hassan, G. (2014). Slum rehabilitation Projects: their Sustainability, and Beyond,. 6 th International Conference. مؤتمر ات كلية الهندسة.

[5] Abdelhalim, K. (2010). Participatory upgrading of informal areas: A decision-makers' guide for action. Participatory Development Programme in Urban Areas (PDP) in Egypt.

[6] Adama, O. (2020). Slum upgrading in the era of World-Class city construction: the case of Lagos, Nigeria. International Journal of Urban Sustainable Development, 12(2), 219--235.

[7] Adelekan, I. (2010). Vulnerability of poor urban coastal communities to flooding in Lagos, Nigeria. Environment and urbanization, 22(2), 433450.

[8] Ajayi, O., Oviasogie, F., Azuh, D., \& Duruji, M. (2014). Urban design and sustainable development: a case of Makoko area of Lagos State, Nigeria. 1st Mediterranean Interdisciplinary Forum on Social Sciences and Humanities, MIFS. Beirut, Lebanon.

[9] Akinsete, E., Hoelzel, F., \& Oshodi, L. (2014). Delivering Sustainable Urban Regeneration in Emerging Nations: Introducing Neighborhood Hotspots. Journal of Architectural Education, 68(2), 238--245.

[10] Alamsyah, P., \& Jamil, M. (2020). THE KOTAKU: STUDY OF THE NATIONAL SLUM UPGRADING PROGRAM SUSTAINABLY IN COASTAL AREAS. 213- 220. doi: https://doi.org/10.18551/rjoas.202011.25

[11] Aluko, O. (2010). The Impact of Urbanization on Housing Development: The Lagos Experience, Nigeria. Ethiopian journal of environmental studies and management, 3(3).

[12] Budiarto, L. (2003). Dwellers and strangers: Socio-cultural entity, spaceuse, and spatial configuration in kampung settlements of Jakarta, Indonesia.

[13] Calderon, C. (2009). Learning from Slum Upgrading and Participation: A case study of participatory slum upgrading in the emergence of new governance in the city of Medellín,Colombia. VDM Verlag Dr. Müller.

[14] Cheema, S. (2020). Governance for Urban Services: Access, Participation, Accountability, and Transparency. Springer Nature.

[15] Cronin, V., \& Guthrie, P. (2011). Alternative approaches to slum upgrading in Kibera, Nairobi. Proceedings of the Institution of Civil Engineers - Urban Design and Planning, 164. doi:10.1680/udap.2011.164.2.129

[16] Dewi, E., Santosa, H., \& Defiana, I. (2015). Sustainable Fisherman settlement Arrangement Concept for Improving Slum Area in Bangkalan Regency. International Journal of Engineering Research \& Technology (IJERT), 4(6), 712--719.

[17] Dianingrum, A., Faqih, M., \& Septanti , D. (2017). Development of kampung improvement program in Surabaya, Indonesia. Int. J. of Eng. and Sci, 7, 41-47.

[18] Ehigiator, P. (2013). Urban Slum Upgrading and Participatory Governance (PG): An investigation into the role of slum communitybased institutions in tackling the challenges of slums in developing nations the case of Lagos state, Nigeria. Malmö högskola/Kultur och samhälle.

[19] Ehigiator, P. (2013). Urban Slum Upgrading and Participatory Governance (PG): An investigation into the role of slum communitybased institutions in tackling the challenges of slums in developing nations the case of Lagos state, Nigeria.

[20] El Hefnawi, A. (2008). Evaluation of the project "Participatory Slum Upgrading in El-Hallous and El-Bhatini, Ismailia, Egypt". Forbes Davidson, Institute for Housing and Urban Development Studies, The Netherlands.

[21] euromedina.org. (2015). Participatory Slum Upgrading in El-Hallous and El Bahtini - Euromedina. Retrieved from Yumpu: https://www.yumpu.com/en/document/view/30991384/participatoryslum-upgrading-in-el-hallous-and-el-euromedina

[22] Fika, O. (2008). development and consolidation of water communities. The Case study of Makoko the landless slum along Lagos Lagoon, Nigeria. Retrieved from http://hdl.handle.net/2105/12140
[23] Flinck, M. (2017). lum Upgrading and Community Participation - A case study on slum upgrading in Kibera. Lunds universitet.

[24] HABITAT, U. (2010). Participatory Slum Upgrading in El Hallous and El Bahtini. Retrieved from UN HABITAT: https://mirror.unhabitat.org/content. asp?cid=686\&catid=192\&typeid=13

[25] Habitat, U. (2015). A Practical Guide to Designing, Planning, and Executing Citywide Slum Upgrading Programme. UN-Habitat Nairobi.

[26] Hamdi, N., \& Goethert, R. (1997). Action planning for cities. England: John Wiley \& Sons Ltd.

[27] Hassan, G. (2012). Regeneration as an approach for the development of informal settlements in Cairo metropolitan. Alexandria Engineering Journal, 51(3), 229--239.

[28] Hoelzel, F., Akinsete, E., \& Partner, G. (2015). Towards a new community-led governance approach, integrating the global into the mundane and why design matters. LSE Africa Summit Special Issue.

[29] Hoelzel, F., Ummuna, M., \& Morka, F. (2014). Makoko-Iwaya Waterfront: Economic Opportunities.

[30] Imparato, I., \& Ruster, J. (2003). Slum Upgrading and Participation: Lessons from Latin America (Directions in Development). World Bank Publications.

[31] Ismailia, T. G. (2005). Participatory slum upgrading Project in El Hallous and El Bahtini.

[32] Judd, K., \& Adams, B. (2016). 2030 Agenda and the SDGs: Indicator framework, monitoring and reporting.

[33] Kotaku Program. (2017). Retrieved from The Cities Without Slums (Kotaku) Program: http://kotaku.pu.go.id/page/6880/tentang-programkota-tanpa-kumuh-kotaku\#

[34] Majale, M. (2008). Employment creation through participatory urban planning and slum upgrading: The case of Kitale, Kenya. Habitat International, 32(2), 270-282. doi:10.1016/j.habitatint.2007.08.005

[35] Oyinloye, M., Olamiju, I., \& Popoola, O. (2017). Urban renewal strategies in developing nations: A focus on Makoko, Lagos State, Nigeria. Journal of Geography and Regional Planning, 10(8), 229--241.

[36] Restrepo Rico, S. (2017). PARTICIPATORY INTEGRAL UPGRADING IN LATIN AMERICA: The Importance of Participatory Practices for Urban Upgrading Programmes. Technische Universitat.

[37] Rohimat, D., Rahmawat, R., \& Seran, G. G. (2018). Partisipasi Masyarakat dalam Implementasi Program KOTAKU/PNPM di Kecamatan Ciawi. JURNAL GOVERNANSI, 3(2), 71 - 80. doi:https://doi.org/10.30997/jgs.v3i2.933

[38] Sari, A., Suman, A., \& Kaluge, D. (2018). Implementation Analysis of Participative Development in National Slum Upgrading Program [KOTAKU]. IJEBD International Journal Of Entrepreneurship And Business Development, 2(1), 17- 35.

[39] Septanaya, I., Rahmawati, D., Navitas, P., \& Stefanugroho, P. (2020). What sets it apart from the rest? Investigating the national slum upgrading program, KOTAKU, in Surabaya. IOP Conference Series: Earth and Environmental Science. 562. IOP Publishing.

[40] Shehayeb, D. (2009). Advantages of living in informal areas. Cairo's informal areas between urban challenges and hidden potentials. Cairo: GTZ Egypt and Participatory Development Programme in Urban Areas (PDP), 34-37. $\quad$ Retrieved from http://www.old.citiesalliance.org/sites/citiesalliance.org/files/CA_Docs/r esources/Cairo\%27s\%20Informal\%20Areas\%20Between\%20Urban $\% 20$ Challenges\%20and\%20Hidden\%20Potentials/CairosInformalAreas_fullt ext.pdf

[41] Shirleyana, S., \& Anindya Sari, A. (2012). THE EMERGENCE OF INFORMAL RIVERSIDE SETTLEMENTS AND CHALLENGES FOR PLANNING: THE CASE OF KALI MAS IN SURABAYA, INDONESIA. Urban Deprivation : A Challenge to Sustainable Urban Settlements. Jakarta - Indonesia: Research Institute for Human Settlements.

[42] Sulistyo, B., \& Widjajanti, W. (2018). Assessment of The Existence of Green Open Space in Fishermen Village. 1977(1), 1-7. doi:10.1063/1.5042973

[43] Sunarti. (2009). HOW IS A STRATEGY FOR SUSTAINABILITY OF COASTAL SLUMS AREA IN REMBANG CITY, REMBANG DISTRICT? Diponegoro University Semarang.

[44] Udo-Udoma, O. (2014). World Bank Public Participation Policies and Processes in Relation to the Lives of Beneficiaries in Slum Upgrading Projects: Case Study: Makoko, Lagos, Nigeria. PhD diss., University of Cape Town, South Africa.

[45] UN Millennium Project . (2005). Taking action: Achieving gender equality and empowering Women. Task force on education and gender 
Equality. The united nations development programme (UNDP). Earthscan london sterling, VA. UN Millennium Project.

[46] UNDP. (2011). Participatory Slum Upgrading. Documented Experience from Ismailia, Egypt. United Nations Development Programme.

[47] UN-Habitat. (2003). The Challenge of Slums: Global Report on Human Settlements. Management of Environmental Quality: An International Journal, 15(3). doi:10.1108/meq.2004.15.3.337.3

[48] UN-Habitat. (2020). UN-HABITAT - REGIONAL OFFICE FOR AFRICA- SUB-SAHARAN AFRICA ATLAS. UN-Habitat.

[49] Vaidya, A., \& Mayer, A. (2016). Critical Review of the Millennium Project in Nepal. Sustainability, 8(10). doi:10.3390/su8101043

[50] Wahab, B. (2017). Transforming Nigerian Informal Settlements into Liveable Communities: Strategies and Challenges.

[51] Wardhani, D. (2017). COASTAL COMMUNITY PARTICIPATION IN KELURAHAN SUKOLILO, BULAK, BASED ON LOCAL ECONOMY. DIMENSI (Journal of Architecture and Built Environment), 44(1), 21-28. Retrieved from https://dspace.uc.ac.id/handle/123456789/1185

[52] Wardhani, D. K. (2017). Coastal Community Participation in Kelurahan Sukolilo, Bulak, Based on Local Economy.

[53] Yopiannor, F., \& Wibowo, N. (2019). Collaboration in Implementation of Kota Tanpa Kumuh (KOTAKU) Program in Palangka Raya City. Iapa Proceedings Conference, (pp. 574--595). Bali.

[54] Zaenal, A. (2019). IMPLEMENTATION OF KOTA TANPA KUMUH (KOTAKU) PROGRAMS TO ENHANCE THE COMMUNITY WELFARE IN MALANG CITY, EAST JAVA, INDONESIA. Proceeding International Conference 2019 (pp. 552 - 557). Malaysian Association of Social Worker.

[55] Zain, D., Salman, D., \& Baja, S. (2018). Model of slum area management based on socio-spatial approach. The case of Baubau City, Indonesia. Journal of Settlements and Spatial Planning, 9(2), 103 - 115.

\section{Arabic Title}

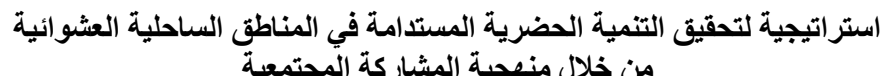

\section{Abstract in Arabic:}

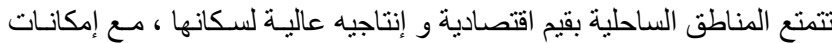

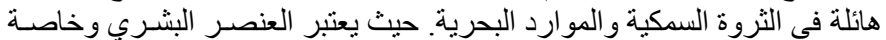

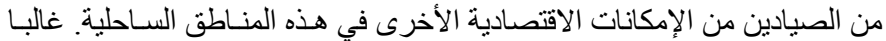

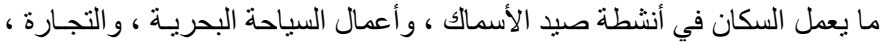

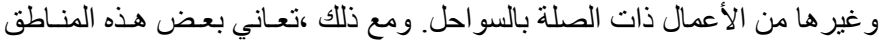

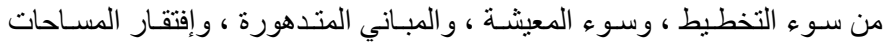

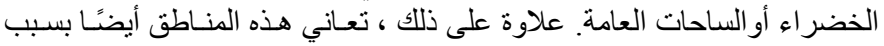

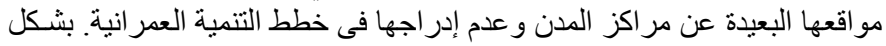

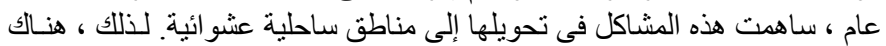

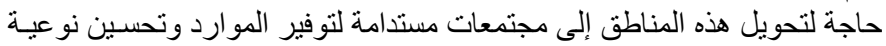
الحياة وتمكين سكانها.

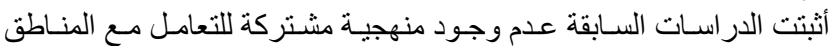

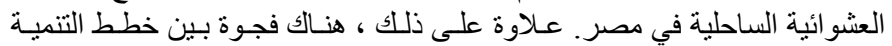

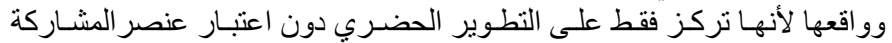

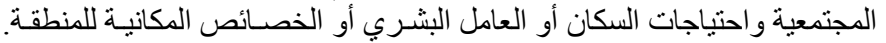

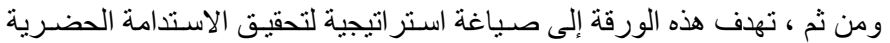

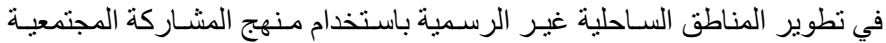

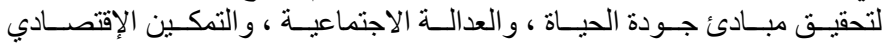

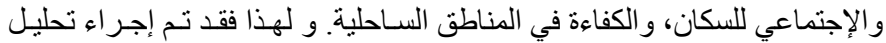

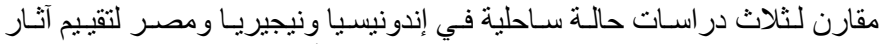

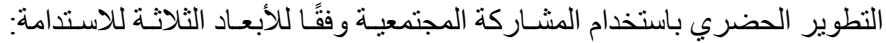
الاجتماعية و الاقتصادية و البيئية.

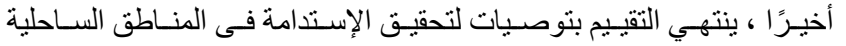

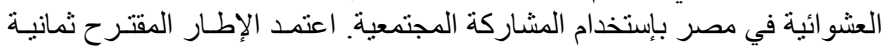

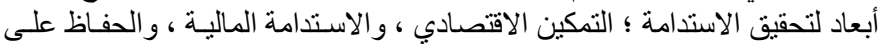

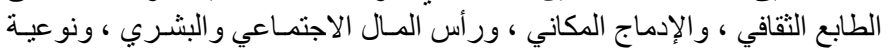

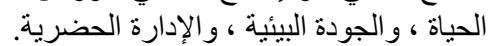

